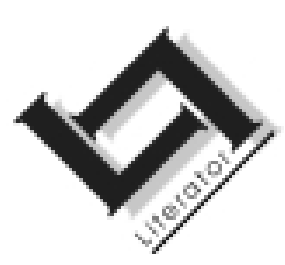

\title{
Waterslangverhale in Afrikaans: die relevansie van mitisiteit
}

\author{
Jean Lombard \\ Afdeling Afrikaans \\ Universiteit van Namibië \\ WINDHOEK \\ E-pos: JeanLombard3@aol.com
}

\begin{abstract}
Watersnake stories in Afrikaans: The relevance of mythicity
\end{abstract}

This article focuses on the reworking of the mythological motif of the water snake in Afrikaans literature. Water snake stories form part of the very first examples of Afrikaans texts in written form, whereas since the end of the twentieth century water snake symbolism has received renewed attention. The analyses of a selection of Afrikaans narratives are performed by utilising the concept of mythicity - a concept which can be defined as the conscious intention to probe the numinous dimensions of human existence by means of literature. The delicate balance between numinosity and narrativity is used as basis for the analysis and evaluation of the texts. The mythic potential of a narrative is not always fully realised, owing either to either restricting ideological and moralistic intentions or excessive association regarding the mythological symbol. The following texts are discussed: Jakob Platjie by G.R. von Wielligh (1917), Die eerste lewe van Adamastor by André P. Brink (1988), Meraai van Rolbos by Charlotte de Beer (1989) and Die donker melk van daeraad by George Weideman (1994). The texts are not, however, discussed in chronological order. The relevance of mythicity is specifically illustrated in the Weideman anthology with its positioning of water snake symbolism in a specific historical context whilst simultaneously exploring universal dimensions.

\section{Opsomming}

Waterslangverhale in Afrikaans: die relevansie van mitisiteit

In hierdie artikel word gefokus op die verwerking van die mitologiese motief van die waterslang in die Afrikaanse letterkunde. Waterslangverhale maak deel uit van die heel vroegste voorbeelde van 
Afrikaanse tekste in geskrewe vorm; sedert die einde van die twintigste eeu het waterslangsimboliek opnuut weer aandag gekry. Die analise van 'n aantal geselekteerde Afrikaanse verhale word gedoen met behulp van die konsep mitisiteit, wat gedefinieer kan word as die bewuste intensie om die numineuse dimensies van die menslike bestaan deur middel van literatuur te peil. Die fyn balans tussen numinositeit en narratiwiteit word gebruik as basis vir die analise en evaluering van die tekste. Die mitiese potensiaal van 'n verhaal word nie altyd volledig verwesenlik nie, wat toegeskryf kan word aan óf inperkende ideologiese of moralistiese intensies óf oormatige assosiëring met die mitologiese simbool. Die volgende tekste word bespreek: Jakob Platjie deur G.R. von Wielligh (1917), Die eerste lewe van Adamastor deur André P. Brink (1988), Meraai van Rolbos deur Charlotte de Beer (1989) en Die donker melk van daeraad deur George Weideman (1994). Die tekste word egter nie in chronologiese volgorde bespreek nie. Die relevansie van mitisiteit word by uitstek aan die hand van die Weideman-bundel geïllustreer, met die plasing van waterslangsimboliek in 'n spesifieke historiese konteks terwyl universele dimensies terselfdertyd ontgin word.

\section{Inleiding}

Hierdie artikel sluit ten nouste aan by 'n verbandhoudende artikel in hierdie nommer van Literator, naamlik "Mitisiteit as basis vir vergelykende literatuurstudie, met verwysing na waterslangsimboliek." In genoemde artikel is 'n teoretiese uiteensetting gegee van die funksionering van mitisiteit, hoofsaaklik aan die hand van 'n aantal sentrale begrippe wat direk daarmee verband hou. Dit het ook geblyk dat die potensiële mitisiteit van 'n teks nie altyd voldoende gerealiseer word nie. In hierdie artikel word die werking van mitisiteit op konkrete wyse geïllustreer deur die oorsigtelike analise van 'n aantal geselekteerde Afrikaanse waterslangverhale. Die relevansie van mitisiteit word bevestig waar die waterslangsimboliek op geslaagde wyse voortgesit word; Die donker melk van daeraad deur George Weideman (1994) geniet die meeste aandag in hierdie verband. Ander tekste word ook kortliks betrek ten einde verdere aspekte van die funksionering van mitisiteit te illustreer.

Mitisiteit kan kortliks omskryf word as die ingesteldheid of bewussyn wat gepaardgaan met die doelbewuste intensie om die numineuse deur middel van literatuur - veral narratiewe vorme - te peil (vgl. Gould, 1981). Dit is helaas 'n doelstelling wat van meet af aan onbereikbaar is, aangesien die numineuse te make het met die onpeilbare of onuitspreeklike dimensies van die menslike bestaan. Tog word talige pogings voortdurend aangewend - veral deur middel van narratiewe tekste met mitiese inslag - om die on- 
begryplike meer begrypbaar te maak. Mitisiteit het dus te make met die voortgesette verwerking van oeroue mitologiese simbole in moderne vorm.

Die buitengewoon groot waterslang, met die wonderbaarlike steen op die voorkop, kom as mitologiese simbool reeds in die vroegste geskrewe Afrikaanse tekste voor, naamlik in die versamelings Diereen Boesmanstories van G.R. von Wielligh, wat tussen die jare 1917 en 1922 gepubliseer is. Die ontginning van die waterslangsimboliek word met gereelde tussenposes in die Afrikaanse letterkunde voortgesit, byvoorbeeld deur Minnie Postma (vgl. die versameling Sotho-verhale As die maan oor die lug loop, 1986), M.I. Murray (Witwater se mense, 1974) en André P. Brink (Die eerste lewe van Adamastor, 1988). Daar kan selfs sprake wees van 'n oplewing van waterslangsimboliek in die Afrikaanse prosa vanaf die begin van die negentigerjare van die vorige eeu. Verhale uit dié tyd waarin die waterslang 'n rol speel, is onder meer: Die dagstêrwals deur Johnita le Roux (1994), In die omtes van die hart deur Petra Müller (1995), Rooigrond deur Thomas Deacon (1995), lets goeds uit Verneukpan? en Mafoiing deur Elias P. Nel (1998 en 2001 onderskeidelik), en Gif deur Piet van Rooyen (2001).

Die verwysing na 'n mitologiese simbool binne moderne konteks bied egter geen waarborg dat die teks waarin dit voorkom, sonder meer oor mitiese relevansie beskik nie. In die vorige artikel is vanuit teoretiese oogpunt nader ingegaan op die verskillende wyses waarop die verskraling van mitisiteit kan plaasvind, veral deur enersyds oormatige assosiëring rondom die simbool, en andersyds fiksering of inperking daarvan as gevolg van ideologiese en/of moralistiese doelstellings aan die kant van die skrywer. In die eersvolgende paragrawe word uiteengesit hoe verskillende Afrikaanse tekste, met waterslangsimboliek as gemeenskaplike mitologiese motief, mitisiteit op mindere of meerdere geslaagde wyse na vore laat tree.

Eerstens word 'n vry uitvoerige ontleding van die drie waterslangverhale uit George Weideman se Die donker melk van daeraad gedoen (2.1). Hulle kom reg aan die begin van die bundel voor, maar daar is talle ander verhale waarin die slang- en steensimboliek resoneer. Hoewel dié bundel as die mees geslaagde voorbeeld van die funksionering van mitisiteit rondom die waterslangsimbool voorgehou word, sal blyk dat problematiese aspekte tog rondom die talle verwysings na ander mitologieë asook eie assosiërings van die skrywer na vore tree. Ondanks groot potensiaal tot mitisiteit, word dit in Die eerste lewe van Adamastor deur André P. Brink (2.2) 
ondermyn as gevolg van oormatige assosiëring en ideologisering. Die nadelige uitwerking van oordrewe moralisering op mitisiteit word geillustreer aan die hand van Jakob Platjie deur G.R. von Wielligh en Meraai van Rolbos deur Charlotte de Beer (2.3). In die laaste afdeling (3) word 'n aantal gevolgtrekkings gemaak, asook voorstelle vir verdere ondersoek.

\section{Teksontledings: spesifieke funksioneringswyses van mitisiteit}

\subsection{Die donker melk van daeraad deur George Weideman (1994)}

'n Opvallende aspek van die waterslangsimboliek in Die donker melk van daeraad is dat dit in eerste instansie konkreet in ' $n$ kenbare realiteit of historiese konteks gegrond is. Dit gaan om die waterslang van 'n spesifieke rivier - die Oranje- of Gariep- of Grootrivier - wat deur 'n heel bepaalde streek vloei. Weideman gee in sy ganse oeuvre besondere aandag aan die gebied van die Noord-Kaap, veral aan die mondelinge vertellers van dié gebied, teenoor wie hy op heel opsigtelike wyse sy skatpligtigheid erken (vergelyk die foto van Elsie en Ruiter van Onseepkans voor in die bundel).

In 'n artikel deur Weideman (1993), wat in Tydskrif vir Letterkunde verskyn het met die titel "Van halfmense en volmense", skryf hy oor die algemeen oor die verhouding mens en natuur. Hy verwys na voorbeelde uit die Afrikaanse letterkunde, maar lig sy beskouings toe met verwysing na konkrete omstandighede in die NoordwesKaap. Hy skryf met name oor die Richtersvelders en die Riemvasmakers, twee gemarginaliseerde groepe wat onder 'n apartheidsregering uiteenlopende ervarings ten opsigte van grondonteiening langs die Oranjerivier moes deurmaak. Weideman kom tot die gevolgtrekking dat daar 'n noue samehang bestaan tussen enersyds die behandeling van mense asof hulle rondskuifbare objekte is, en andersyds 'n gebrek aan ekologiese visie.

Hierteenoor pleit Weideman $(1993: 12,14)$ vir 'n holistiese visie:

Dis eenvoudig dít: dat alles wat ons sê en skryf en doen op die ou end met ons plek - ons bestaansruimte - binne die groter geheel te make het. Daardie groter geheel is lééfomgewing dis ruimte vir die Self en ruimte vir die Ander. Om te skryf, is om óm te gee ... 'n Breër, volledig-mensliker visie is nodig, en ons is dit verskuldig aan hulle wat nog kom dat daardie visie die 
simbiotiese verwantskap tussen aarde en aardbewoner en aardbewoners onderling minstens as 'n soort matrys - juis, volgens die Grieks: baarmoeder - voorstel.

Hierdie visie dien as belangrike aanvulling tot die twee belangrikste intensies waaroor dit in Die donker melk van daeraad gaan, naamlik (a) 'n herwaardering van die orale ekspressie en (b) die oproep tot 'n holistiese visie wat die intrinsieke, ekologiese verhouding tussen mens en natuur opnuut wil bevestig.

\subsection{1 "(Matrys)"}

Die titel van hierdie eerste verhaal in die bundel sluit direk aan by bogenoemde aanhaling uit die Weideman-artikel. In terme van die algemene Afrikaanse woordeboekbetekenis kan die "(Matrys)"verhaal inderdaad as 'n soort "gietvorm" of "model" vir die res van die bundel beskou word. Nie net waterslangsimbole nie, maar ook baie ander deurlopende motiewe word aan die orde gestel. Met die Griekse betekenis van die woord, naamlik "baarmoeder", word assosiasies met "begin" en "geboorte" opgeroep; ook met die getal "nege", wat voortdurend in die bundel (bestaande uit nege onderafdelings) resoneer. Die titel tussen hakies kwalifiseer terselfdertyd die moontlikheid dat die verhaal as sleutel tot die bundel kan dien, 'n tipiese illustrasie van die "oopheid" en ironie wat met mitisiteit gepaard gaan.

In die inleidingsparagrawe formuleer die implisiete skrywer die waarde wat vertellings soos dié van die Nama-vertellers Elsie en Ruiter vir hom het. As kind het hy weinig verstaan van wat hulle vertel het, en het hy slegs "agter die verwondering aan" (p. 1) 1 geluister. Die orale erfenis word egter al hoe meer deel van sy eie mitiese vertelprosesse: "Noudat ek ouer is, soek ek formules en patrone, maar hoe meer ek weet, hoe minder verstaan ek." (p. 1) Ná dié proloog deur die verteller-skrywer, wat as Weideman self gedui kan word (vergelyk die aanspreekvorm "Jorsiegoed") neem Elsie oor en vertel die storie "van die steen wat weggeraak het" (p. 1).

Sy vertel eintlik twee verhale - die een ingebed in die ander - met kortliks 'n verwysing na 'n derde een. Die eerste verhaal handel oor die jong meidjie, Dairos, en haar mense se eerste kennismaking met die blankes wat met hul skepe oor die see gekom het. Die Nama-

1 Bladsynommers tussen hakies verwys na Weideman, George. 1994. Die donker melk van daeraad. Kaapstad : Tafelberg. 
mense het hul kosbaarste besitting, die magiese steen met die naam "Kleur van die nag net voor die dag breek", vir die wit mense gewys, wat dit toe met mag vir hulleself toegeëien het. Die steen is in die hande gekry toe Waterslang dit neergesit het terwyl hy gaan wei het in die veld. Die verhaal wat die uitvoerigste vertel word, is dié van Dairos se oupa wat in 'n nog verdere verlede aangebied het om die steen te gaan terugwen nadat Waterslang dit self kom terugvat het. Wat volg, is 'n verhaal met 'n tipiese sprokiestruktuur en vier moontlike eindes. Weideman skryf dus met 'n besef van postmodernistiese konvensies (byvoorbeeld metafiksionaliteit en meervoudige eindes; vgl. Lombard, 1988), maar benut terselfdertyd verteltegnieke uit ' $n$ orale tradisie wat ver in die verlede teruggaan. Die meerdere eindes is ' $n$ verdere manifestasie van die relativering wat dikwels met mitisiteit gepaard gaan.

Reg aan die einde van hierdie meervlakkige verhaal vra die verteller wat dan van Dairos en die mense van die skip geword het. Heel argeloos sluit Elsie af: "Dairos se mense het hulle nágesit tot kortby Grootkuil. Toe sien hulle: die mense is daar ín. En hulle het geweet: uit sal hulle nooit weer daar uitkom nie" (p. 8). Hierdie slot simboliseer op kernagtige wyse 'n lang geskiedenis van kolonialisering én dekolonialisering. Die steen van die "Ander" word met mag deur die witman afgevat, wat laasgenoemde in "Grootkuil" laat beland. Uiteindelik sal daar nie uitkomkans wees nie, want Waterslang gaan wraak neem - 'n gegewe wat geïnterpreteer kan word as 'n vooruitwysing na gebeure so onlangs as die politieke veranderings in SuidAfrika vanaf 1994.

Die ingebedde verhale van hierdie sleutelverhaal verteenwoordig tipiese aspekte van die mitiese vertelproses. Die numineuse dimensies van die steen bly deurgaans die hoofrede waarom Elsie vertel: dit gaan om "paljas-se-steen" wat steeds gevind en behou moet word. Wanneer Elsie vertel van Dairos se oupa wat die steen gaan soek, word die numineuse heel duidelik geskakel met die narratiewe, deur spanning en konflik wat opgebou word rondom die verskillende gevare wat hy moet trotseer. Met Dairos se verhaal, waar die steen deur die witman gevat word, word hierdie spanning tussen die numineuse en die narratiewe geplaas binne 'n definitiewe historiese konteks. So word die voortdurende werking van die argetipiese simbool - die waterslang met die wonderbaarlike steen binne 'n bepaalde historiese verloop gewaarborg.

In die tweede afdeling van die bundel, wat volg op die drie waterslangverhale, word duidelike parallelle met die slot van die "matrys"-verhaal getrek. In die vertelling "Die paddas" word motiewe 
van mag en vergelding opgeroep. Die res van die afdeling bestaan uit drie verhale wat Weideman (1995:12) self as "militêre" verhale tipeer. Die spesifieke deel van die Suider-Afrikaanse apartheidsgeskiedenis wat hier betrek word, is naamlik "Suidwes se onafhanklikheid" (p. 42) en Suid-Afrika se militêre betrokkenheid in Namibië en Angola. Spesifiek in die verhaal "'n Kwessie van timing" word die steensimboliek ontgin binne die relatief moderne konteks van die grensoorlog. Dit handel oor jong soldate wat vanaf 'n trein, waarskynlik op die lyn vanaf De Aar na Windhoek, muntstukke vir jong bruin of swart kinders ("gamsekind", p. 32) gooi. Die muntstukke word vooraf met 'n sigaretaansteker vuurwarm gemaak, en dan is dit 'n groot grap wanneer die kinders hulle hande verbrand in hul gretigheid om die geld in die hande te kry. Maar op 'n dag het daar weerwraak gekom: die kinders het teruggegooi. 'n Kelner op die trein vertel hoe een van die soldate op slag dood is toe 'n baksteen hom teen die kant van die kop getref het. Hyself is gewond: "daai tweede baksteen vang my hier, sien jy dié merk; ek is nou vir my vierde operasie in, en ek sukkel nog altyd om te slaap" (p. 32). Danksy die oopheid en trefkrag van argetipes soos die waterslang en die gepaardgaande steen, kan betekenisassosiasies beginnende by die "primitiewe" mitologiese simbool deurgevoer word tot op die vlak van relevante, sosiaal-politieke kommentaar op 'n definitiewe historiese realiteit in moderne konteks.

\subsection{2 "Die waternôientjie"}

Hierdie verhaal word omskryf as "die halfvoltooide verhaal van die verlamde jong man (Jakob Wieland - JL), en Tos en die Waternôientjie" (p. 10). Die jongmeisie, Tos, sterf op geheimsinnige wyse; haar liggaam word in die rietbos langs die rivier gekry. Volgens haar ma, Jakob se "Antie", is dit "Waternôientjie" se werk" (p. 9). Haar man, Mannetjies, sê weer dit is 'n "doodmaakding" by die rivier wat "Otterbaas" (p. 9) genoem word. Daar is, binne die konteks van die bundel, duidelike parallelle tussen die waterslang, die waternôientjie en die otterbaas. Die belangrikste assosiasie rondom die waternôientjie is dié van vroulike seksualiteit; die vroulike kant van die waterslang word dus hier deur Weideman ontgin. 'n Interessante aspek van die verhaal is dat Tos volgens sommige mense die slagoffer word van een of ander waterdier, maar terselfdertyd is sy ook 'n verleidelike waternôientjie (p. 17). Dié soort dubbelslagtigheid kom ook in haar verhouding tot Jakob na vore: sy troos hom, verlei hom en onttrek haar dan.

Deur die loop van die verhaal word gesuggereer dat Tos se eintlike moordenaar ' $\mathrm{n}$ vragmotorbestuurder is, wat voorheen as voorman 
op die plaas gewerk het waar Tos se mense die vrugteplukkers is. Ná Tos se lyk langs die rivier gevind is, het die drywer nooit weer teruggekeer nie. Jakob is verlam omdat hy tydens die vrugteplukkery van 'n leer afgeval het. Volgens gerugte het die wit voorman opsetlik só gery dat Jakob val, omdat die bruinman 'n oog op Tos sou gehad het. Jaloesie speel inderdaad 'n rol, omdat Tos toegelaat het dat die verlamde Jakob, hoewel met 'n verwoeste onderlyf, tog 'n mate van seksuele bevrediging by haar gekry het.

In meer as een opsig wentel hierdie verhaal om gemarginaliseerdes in die samelewing: 'n magtelose plaaswerker soos Jakob, maar ook magtelose skrywers. Die verteller van die verhaal is 'n inspekteur wat die manuskripte ontdek van Jakob se onderwyser, ene John Fransman, wat hom as buitengewoon skrander leerling leer ken het. Fransman sterf in 'n fratsongeluk, voordat hy 'n verhaal gebaseer op Jakob se lotgevalle, kon voltooi. Aan die einde weerhou ook die inspekteur hom van die verwerking van Fransman se manuskripte in 'n afgeronde verhaal, want niks wat hy ooit sal skryf, sal die dooies weer lewendig kan maak of die landelike omgewing teen die ontwikkelende tegnologie en onvermydelike verstedeliking kan vrywaar nie (p. 17). Die mitiese onderbou van die verhaal, met die misterieuse rol van die waternôientjie en verwante verskynsels, vorm dus die basis waarop kommentaar met sowel sosiaal-politieke as ekologiese relevansie binne moderne konteks gelewer word.

In paradoksale samehang met die relevansie van mitisiteit word die nadele van oormatige aandag aan die mite ook in hierdie verhaal geïllustreer. Die mondelinge oorlewering, hier spesifiek oor verskynsels soos die waterslang, kan helaas 'n ontvlugting van die realiteit inhou. Tos se ouers wil nie die werklikheid onder oë sien dat hul dogter moontlik deur ' $n$ witman vermoor is nie. Hul eie posisie as plaaswerkers kan in gedrang kom. Voorts sou hulle nie teen die vragmotorbestuurders wil ingaan nie, omdat hulle weet dat hul ander dogters 'n inkomste verdien deur prostitusie onder die vragmotorbestuurders; trouens, ook in die stad waarheen die jongmense een na die ander verhuis. Hulle soek dus ontvlugting in die verklaring dat óf "waternôientjie" óf "otterbaas" Tos se dood veroorsaak het.

Ten opsigte van die rol van geweld tree insiggewende perspektiewe rondom die waterslang na vore, ook in ander tekste in die bundel. In die verhaal "Die vreemdelingspoeding" word daaroor bespiegel dat geweld in elke individu sluimer en wag om toe te slaan: "Soms lê dit net en wag, diep, diep onder die water van die onbewuste, en dit wag op die geringste plons wat die oppervlak versteur" (p. 85). Die metafoor wat gebruik word, is dié van 'n watermonster of "water- 
ding", soos die waternôientjie, otterbaas of waterslang. Tydens 'n voorlesing oor die bundel toon Weideman dat hy hom terdeë bewus is van die rol van die onbewuste in die skryfproses. Hy sê onder meer (1995:11-12): "Van die oustories in die bundel wil ... 'n brug slaan tussen die 'donker onbewuste' (wat natuurlik 'n kollektiewe is: daarom is dit juis ou stories, sprokies en legendes en oorvertellings en aanlapstories wat hulself telkens 'kamoefleer')." So 'n soort uitspraak bevestig die beskouings van Jung, naamlik oor die onbewuste as eintlike oorsprong van mitisiteit (vgl. die voorafgaande artikel oor mitisiteit as vergelykingsbasis).

\subsection{3 "Die wonderslang"}

Die derde waterslangverhaal roep duidelike assosiasies met enersyds die Voorwoord en andersyds die verhaal "Die waak" op. Dit gaan naamlik oor nege kinders wat rondom hul moeder se sterfbed bymekaargekom het en wonder wie 'n baie kosbare erfstuk gaan kry. Tante Marta, die sigeunertante in die familie, sou van haar swerwer-voorsate 'n kosbare edelsteen in die vorm van 'n skarabee geërf het. Om die tyd te verwyl, vertel die tweelingseuns, die ooms Quartus en Quintus, die verhaal van die "wonderslang", soos hulle dit gehoor het by ene Johannes Cloete. Hy is 'n transportryer wat, terwyl hy aan die houtry was vir die myne, van Concordia af Grootrivier toe, op 'n keer die wonderslang gesien het. Oom Quartus tipeer dit as 'n "snertstorie" (p. 18) of "liegstorie" (p. 21), maar sonder dat hy dit besef, verraai die verhaal sommige aspekte van hul diepste begeertes: 'Nee, ek sê mos, dis natuurlik alles kak,' sê oom Quartus en oom Quintus beaam, maar in albei se oë is daar iets verlangends" (p. 25).

'n Hele aantal van die tipiese eienskappe van die Grootslang word weergegee, maar die steen op die voorkop is die prominentste eienskap: "die slang dra 'n steen voor sy kop, 'n blinke, sê party, en ander sê dis 'n rooie, 'n ruby, maar 'n reusesteen". Deur middel van dié juweel, ook "amulet" (p. 161) of "talisman" (Voorwoord) genoem, word die blink steen van die waterslang in verband gebring met die skarabee of miskruier. In die graftombes van die ou Egiptenare is kosbare juwele in die vorm van die skarabee aangetref, dikwels uit goud gemaak met 'n spesiale juweel tussen die voorpote wat die bol mis moet voorstel. Die voorblad van die bundel toon 'n illustrasie van so 'n skarabee-juweel. Binne die Egiptiese mitologie verteenwoordig die skarabee die songod, $\mathrm{Ra}$, heerser oor die duisternis en die dood. 
In die Voorwoord tot die bundel, wat 'n belangrike funksie ten opsigte van die teksintensie vervul, word die padda en die miskruier eksplisiet met mekaar in verband gebring:

Is dit so vreemd dat vir die ou Egiptenare - wie se hele bestaan deur woestyn en Nylrivier bepaal is, net soos die nedersetters langs ons riviere - die miskruier en die padda simbole van herrysenis en 'n lang lewe geword het?

Met die verwysing na "ons riviere" word die waterslang ook implisiet betrek by die padda- en die skarabeesimboliek. Die historiese konteks van die waterslang van die Oranjerivier word dus direk geassosieer met die Egipitiese mitologie. Weideman betrek ook ander mitologiese stelsels in die bundel. In "Die waternôientjie" word die Yslandse Eddas met die naam Jakob Wieland in verband gebring. As gevolg van tante Marta se sigeunerverbintenis speel die Hongaarse mitologie 'n belangrike rol.

Oor die steen - in die Voorwoord spesifiek die skarabee - word die volgende geskryf:

Soms is so 'n skarabee - met 'n gloeiende karbonkel in die plek van die nederige bol mis - by die gebalsemdes geplaas om hul op hul ewige reis deur die skemer te vergesel. In die donker tombes gloei die stene steeds.

Hierdie embleem ... het in die denke van die mens verword, geslyt tot halssieraad; tot 'n klein korreltjie brein wat die sentrum van ons mag geword het. Tot, selfs, die donker punt aan die einde van 'n sin. Ons het die stiltes en die oneindige variasies van ou, ou stories prysgegee

Dit is opvallend dat die laaste sin van hierdie gedeelte geen punt het nie. Die punt sou kon dui op stelligheid en afgehandeldheid, teenoor die onvoltooidheid van die "ou stories", met hul meerdere eindes, en dus ook die oopheid van mitiese betekenisgewing.

In die verhaal "Die waak" word die temas van boosheid en verwording - direk gekoppel aan die waterslang en die steen eksplisiet aan die orde gestel en verder gevoer. Die landskap word as 'n verworde landskap beskryf: "Selfs die rivier is op sy leegste ooit; oor sommige kuile hang 'n vlies van verrotting" (p. 162). Die kinders is traag om by hul sterwende moeder te waak; die spanning oor wie die juweel gaan erf, is voorop. Hulle begin twyfel of dit hoegenaamd bestaan, en indien wel, of dit enigsins eg is. Die tweeledige simboliek van die skarabee hang saam met hierdie dun grens tussen goed en boos, mooi en verword, werklikheid en illusie. 
Dit is die tweelingbroers Quintus en Quartus se beurt om te waak, maar Quintus slaap al en Quartus kla van 'n pitsweer aan sy nek. Anders as die baie aande toe daar stories vertel is - onder meer "Die wonderslang" - sien hulle daardie aand nie vir stories kans nie. Quartus se klag gee wel aanleiding tot 'n lang, spekulatiewe gesprek (vier bladsye lank) waaraan feitlik al nege kinders en hul eggenotes deelneem. Quartus noem die pitsweer in sy nek 'n "helsteen" en Clarissa, die linguis, wys daarop dat Carbunculus in Latyn "kooltjie vuur" (p. 164) beteken. "Karbonkel" roep nogeens die assosiasie met die juweel of skarabee op. Bertrand wys daarop dat juwele en kosbare gesteentes numineuse waardes verteenwoordig: "hulle is simbole van superieure kennis, van die bo-menslike" (p. 166-167). Clarissa "raai" dat al hierdie dinge "iets met Jung" (p. 167) te make het.

Twee insiggewende formulerings kom in hierdie gedeelte voor wat direk in verband gebring kan word met Jung se teorieë. Hulle is: "Sy klag (dit is Quintus s'n oor die pitsweer - JL) sit 'n ketting woorde aan die gang" (p. 164), en "net die wantroue bly. En die speel met woorde, met oorspronge" (p. 168). Volgens Jung (1964:90) kan argetipes op 'n té oop wyse gehanteer word, met verlies van numinositeit (vgl. nogeens die vorige artikel oor mitisiteit). Quartus se reaksie op Clarissa se verwysing na Jung is "Nee, fok ... nou raak julle te geleerd" (p. 167).

Die interessante is dat Weideman op die mikrovlak van hierdie enkelverhaal, dit wil sê aan die hand van sy karakters se dialoog, spesifiek hierdie insig illustreer: dat die mens in sy misbruik van taal - eindelose kettings van woorde - die argetipiese numinositeit wat potensieel tot elke taaluiting behoort, kan laat verword. Die vraag wat ten opsigte van Die donker melk van daeraad ontstaan, is of Weideman as implisiete outeur in sy oorkoepelende hantering van die argetipiese simboliek - dus in sy omvattende mitiese intensie tot die verwerking daarvan in literêre vorm - self aan hierdie gevaar ontkom. Word daar nie afbreuk gedoen aan die numineuse dimensies van die bundel as gevolg van die eindelose hoeveelheid assosiasies en parallelle wat rondom die waterslang en die wonderbaarlike steen opgebou word nie?

In die Inleiding is daarop gewys dat die verskraling van mitisiteit op hoofsaaklik twee maniere kan plaasvind, naamlik deur oormatige assosiëring en deur inperkende fiksering van die argetipiese simbool, meestal deur middel van ideologiese of moralistiese intensies. Uit die voorafgaande teksanalise blyk dat Weideman sy leser voor besondere uitdagings stel. Daar is by wyse van spreke 
oneindige estetiese plesier te haal uit die nagaan van die talle verwysings rondom sowel die slang as die steen. Die nagaan van álle assosiasies binne byvoorbeeld die Egiptiese en Hongaarse mitologieë sou 'n volledige ondersoek op sigself verg. Dit is belangrik om die "beginne" van 'n mitologiese motief te probeer nagaan ten einde die historiese konteks of kontekste waarbinne dit funksioneer, goed te begryp. Verder bevestig nuwe assosiasies wat 'n skrywer tot stand bring juis die dinamiese werking van mitisiteit. Tog bly die peiling van die numineuse net so 'n belangrike aspek as die narratiewe ontginning en assosiëring. Die volledige naspeur van die ontstaan en verspreiding van 'n bepaalde mitologiese motief is nie 'n doel op sigself wanneer dit in die eerste plek gaan oor mitisiteit nie. Die narratiewe verwerkings van die motief moet steeds in hul verhouding tot die numineuse dimensies van die teks geïnterpreteer en geëvalueer word.

Dit gebeur wel van tyd tot tyd in Die donker melk van daeraad dat die leser se aandag weggelei word van die spannende wisselwerking tussen narratiewe en numineuse dimensies vanweë oormatige assosiëring. 'n Goeie voorbeeld hiervan is die direkte assosiasie van die steen met die vroulike geslagsorgaan in die verhaal "Bedelaar", met as hoofkarakter 'n veertigjarige geskeide vrou. Hennie Aucamp (1994:5) noem dié verhaal "bra tydskrifmatig", en Ena Jansen (1994:54) kla dat die verhaal plek-plek "soetsappig" word. Die sentimentaliteit van die verhaal, veral in die slot, kan onder meer toegeskryf word aan 'n té direkte verbandlegging tussen die twee komponente van die beeld. Daarby kan ook gevoeg word die gebrek aan inagneming van die historiese konteks van die simbool: die steen word hier heeltemal los gesien van haar allegoriese "bron", naamlik die waterslang binne 'n lang voorafgaande tradisie van ander waterslangverhale. Aucamp (1994:4-5) noem as kritiek teen die bundel dat verhale "vereenders" as gevolg van al die toe- en inspelings van die onderlinge verhale. Vanweë al die assosiasies en parallelle wat rondom die waterslang, verwante verskynsels en die steen opgebou word - deur middel van aanverwante verskynsels maar ook "internasionale" waterslange gebeur dit dat die waterslang van die Oranjerivier in sekere sin sy unieke aard - en belangriker nog - dié van sy streek prysgee. 'n Sentrale aspek van die bundel, naamlik die ontginning van 'n spesifieke historiese streek en sy mense, word hierdeur in gedrang gebring.

Die voordeel van die universalisering van die waterslangmotief is egter dat Weideman daarmee grootliks verhoed dat sy verhale 
primêr in diens van spesifieke ideologiese of moralistiese belange gelees word, al spruit hulle in die eerste plek voort uit 'n heel spesifieke historiese konteks. Die feit dat die waterslang by die onderlinge verhale in 'n vergelykingsperspektief met ander belangrike religieuse simbole in verband gebring word, waarborg dat die mitisiteit van hierdie simbool nie deur ideologiese oorwegings verskraal word nie. Dit is opvallend dat daar geen doelbewuste problematisering van die verhouding tussen godsdienste voorkom nie. Elemente uit waterslangverhale en Bybelse verhale word met groot vanselfsprekendheid onderling gekombineer, as gevolg waarvan oormatige moralisering vermy word. Terselfdertyd word erkenning gegee aan die mitologiese oorspronge van baie Bybelverhale, byvoorbeeld dié van Noag, wat parallelle het in die bekende Gilgamesj- en ander voor-Bybelse eposse (vgl. Pritchard, 1958 en Winton Thomas, 1958). Daar word dus rekening gehou met die inherent-religieuse en numineuse dimensies van verskynsels soos die waterslang. Die gebrek aan problematisering van verskillende religieuse belewings, byvoorbeeld Westerse tradisies en gelowe vanuit oorwegend Afrika-oorspronge, kan gesien word as 'n besondere geslaagde poging om die wêreld van die Ander byvoorbeeld dié van Elsie en Ruiter - vanuit die perspektief van die wit skrywer te benader.

Kritiek met betrekking tot oormatige assosiëring moet dus nie afbreuk doen aan die merkwaardige bydrae van Die donker melk van daeraad tot die Afrikaanse letterkunde nie. Die bundel verteenwoordig 'n ontginning van mitisiteit binne 'n Suider-Afrikaanse konteks, maar terselfdertyd word die waterslangsimboliek in verband gebring met mitologiese stelsels wat veel wyer strek as dié spesifieke historiese werklikheid. Wat oënskynlik na kontreikuns lyk, word by Weideman deel van 'n relevante, holistiese visie binne postmodernistiese konteks. Op die basis van mitisiteit toon Weideman se werk vergelykingsmoontlikhede met letterkundes van ander tale - binne die Afrikaanse, Engelse en Nederlandse letterkundes, maar ook veel wyer. In hierdie artikel word vervolgens slegs kortliks gefokus op die vergelyking met ander waterslangtekste in die Afrikaanse letterkunde, ten einde verdere aspekte van die funksionering van mitisiteit nader te illustreer.

\subsection{Die eerste lewe van Adamastor deur André P. Brink (1988)}

Hierdie novelle, gebaseer op die Adamastor-mite en geplaas binne die konteks van die Khoesaan-kosmologie, toon besondere potensiaal tot mitisiteit, juis as gevolg van die moontlike assimilasie van 
Westerse mitologieë en dié uit Afrika. Die gebeure speel af in die V.O.C.-tyd, met as hooffiguur ene T'kama van Khoi-afkoms wat verlief raak op 'n wit vrou wat saam met 'n groep Nederlandse koloniste na die Kaap gevaar het. Die teks kan wel as voorbeeld van postkoloniale literatuur getipeer word, veral aangesien die verteller die verhaal vanuit moderne perspektief aanbied, dit wil sê "hierdie jaar van Onse Here, negentien-soveel- en tagtig" (p. 4). ${ }^{2}$

T'Kama word voorgehou as die eerste inkarnasie van Adamastor. Die Adamastor-figuur is op sy beurt die skepping van die Portugese skrywer Luis Vaz de Camoens wat in 1572 die epos Os Lusíadas geskryf het. Hierin word Adamstor voorgestel as een van die Titaanse reuse wat teen die gode van Olimpus gerebelleer het. ' $n$ Verdere misdryf is sy liefde vir die seenimf, Thetis, 'n vrou ver verhewe bo sy stand. As straf word hy verander in 'n skurwe berg aan die suidpunt van Afrika. As verwoede reus met 'n donker gelaatskleur word hy deur Camoens uitgebeeld as simbool van "donker Afrika", wat deur Portugese helde soos Dias en Da Gama oorwin moes word ten einde die Westerse beskawing in Afrika te vestig. Brink se intensie is onder meer om 'n korrektief te bring op dié Westerse oorheersing. Daarom plaas hy die eerste inkarnasie van die Adamastor-god binne die inheemse mitologie van die Khoekhoen, waarin die waterslang deel vorm van die sentrale simboliek. Die besef aan die kant van die implisiete skrywer van die vele manifestasies van die Adamastor-mite deur die eeue heen is ' $n$ moontlike waarborg vir mitisiteit, omdat die oopheid en dinamiek van die verskillende argetipes hierdeur geïllustreer sou kon word.

Tog ontkom Brink nie aan die gevaar van ideologiese inperking ten koste van mitisiteit nie. Die implisiete skrywer se intensie word soos volg voorgehou: "Dit is my opgaaf vir hierdie geskrif. Met ander woorde: gestel daar was 'n Adamastor, 'n model vir Adamastor, en gestel hy het deur die eeue in baie verskillende, opeenvolgende gedaantes bly voortbestaan" (p. 4). Hoewel hier sprake is van "baie verskillende, opeenvolgende gedaantes" - 'n goeie formulering vir mitisiteit - gaan dit uiteindelik slegs om twee perspektiewe op Adamastor: dié van Camoens en Brink. Die intensie van die novelle, naamlik die verset teen die rassisitiese beskouings van die Portugese skrywer, word as alternatiewe en korrekte "model" aangegee. Dit gaan dus hier eerder om 'n óf-óf-keuse tussen 'n

2 Bladsynommers tussen hakies verwys na Brink, André P. 1988. Die eerste lewe van Adamastor. Kaapstad : Saayman \& Weber. 
Westerse en 'n Afrika-beskouing, eerder as 'n dinamiese assimilasie van mitologieë en wêreldbeelde. Wat die oopheid van die mitiese prosesse in hierdie verhaal verder teenwerk, is dat die einde van die teks gekenmerk word deur 'n definitiewe politieke oplossing, gesimboliseer deur die vooruitskouing op die geboorte van die kind van T'Kama en Khois, wat nuwe hoop en versoening moet bring. Dié soort simboliese werkinge word 'n te gemaklike verteltruuk wat die dinamiese werking van mitisiteit teëwerk.

Die verlies aan potensiële ontginning van mitologiese simboliek word voorts duidelik geïllustreer aan die hand van die waterslangverwysings wat verspreid in die novelle voorkom. Daar is altesaam vyf vermeldings van buitengewone slange, maar slegs een van hulle sluit in werklikheid aan by die tradisie van die waterslang in die Khoimitologie, met name die verwysing na "die Groot Slang met die blink klip op sy kop" (p. 33). Die ander voorbeelde het te make met slange met vuurstene op die voorkop (p. 25), waterslange wat hulself opvreet (p. 25) en vlieënde slange (p. 52). Die laaste vermelding kom voor wanneer 'n krokodil die vrou Khois in 'n rivier wil vang. T'Kama gooi sy lang geslagsorgaan - een van die belangrikste allegoriese aspekte van die verhaal - soos 'n reddingstou na haar toe uit. In die proses trap hy in 'n gat, slaan agteroor en "die onmoontlike voël kom soos 'n waterslang agter my aan" (p. 64).

Brink se fantasering van nuwe assosiasies rondom bestaande mitologiese simbole is inderdaad merkwaardig. Dat hy T'Kama se penis, met allerlei allegoriese assosiasies, ook nog in verband bring met die waterslang, laat hom egter nie ontkom aan wat Jung tipeer as die argetipe wat so "oop" is dat die numineuse dimensies verlore gaan nie. Dié soort uiteenlopende wisselinge wat Brink rondom die waterslangsimbool opgebou het, maak waarskynlik eerder deel uit van sy eie verbeelding as wat dit aansluit by 'n lang mondelinge tradisie van outentieke oorvertellings. Die eerste lewe van Adamastor vertoon dus beide tendense wat mitisiteit teenwerk, naamlik ideologiese inperking én oormatige assosiëring.

' $n$ Verdere interessante aspek is naamlik dat die numineuse in die novelle nie in die eerste plek verband hou met die gode van die Khoekhoen nie. Die enkele kere wat die hoofgode van die Khoekhoen, soos Tsui-//Goab, Heitsi-Eibib en //Gaunab, ter sprake kom, word hulle nie in die eerste plek met religieuse vraagstelling in verband gebring nie (vgl. byvoorbeeld T'Kama se vaste sekerheid dat die wit vrou vir hom voorbestem is, p. 18). In T'Kama se verhouding tot die vrou is daar veel eerder sprake van onsekerheid. Sy momente van nie-wete, wat die numineuse dimensies van die 
verhaal oproep, word nie direk met religieuse of mitologiese verwysings in verband gebring nie. Die onbegrip ten opsigte van die vrou en haar seksualiteit is die primêre oorsaak daarvan.

'n Algemene vraag met betrekking tot mitisiteit wat as gevolg hiervan na vore tree, is naamlik of daar ander vorme van mitisiteit bestaan as net dié wat verband hou met die spanning tussen die numineuse - oftewel religieuse - en die narratiewe. Hoewel daar 'n verskraling van mitisiteit in hierdie novelle plaasvind, kan daar nie gesê word dat dit geensins oor mitiese dimensies beskik nie. Juis die feit dat die mitiese potensiaal rondom die waterslang en verwante simbole uit die Khoesaan-mitologie nie na behore ontgin is nie, roep weer ander vrae rondom die verskynsel mitisiteit op.

\subsection{Jakob Platjie deur G.R. von Wielligh (1917) en Meraai van Rolbos deur Charlotte de Beer (1989)}

Hierdie twee romans - die een relatief resent en die ander bekend as een van die heel eerste geslaagde Afrikaanse verhale - word saam bespreek, omdat albei 'n soortgelyke inperking van mitisiteit illustreer. By sowel Weideman as Brink is gewys op die nadelige uitwerking van oormatige assosiëring; by Brink vind verskraling van mitisiteit ook as gevolg van ideologisering plaas. Sowel Jakob Platjie as Meraai van Rolbos toon dergelike verskraling of inperking as gevolg van moraliserende ingrype deur die skrywer.

Van die vroegste geskrewe tekste in Afrikaans is Von Wielligh se Dierestories (1917-1922) en Boesmanstories (1919-1921), wat hy opgeteken het toe hy aan die einde van die neëntiende eeu as landmeter in Namakwaland en Boesmanland in die Noord-Kaap gewerk het. Die roman Jakob Platjie verskyn in boekvorm in 1917, nadat dit as 'n reeks aflewerings in die eerste Afrikaanse tydskrif, Ons Klijntji, aangebied is. Dit is juis in die vergelyking van die optekening van enersyds die oorspronklik mondeling oorgelewerde verhale en andersyds die roman wat op hulle gebaseer is, dat interessante waarnemings ten opsigte van mitisiteit in Von Wielligh se werk na vore tree.

Von Wielligh het al die tekste wat hy gepubliseer het, van inleidings voorsien, waarin hy sy intensies met die skryfwerk uitvoerig uiteengesit het. Omdat hy Boesman-3 en Griekwaverhale as grond-

3 Daar is reeds in die vorige artikel gewys op die problematiese aard van sowel die term "Boesman" as die term "San". "Boesman" word hier gebruik in 
stof gebruik het ten einde onder meer Afrikaans as selfstandige skryftaal teenoor Nederlands te vestig, het hy hom ook verplig gevoel om heel spesifieke standpunte oor veral die Boesmans se kultuur weer te gee. Dit is veral wanneer hy oor die godsdiens skryf dat die besonder belangrike rol van die waterslang binne die Boesman-verteltradisies pertinent na vore tree.

Ten opsigte van sy verwerking van die Diere- en Boesmanstories verduidelik Von Wielligh hoe hy telkens probeer om 'n middeweg te volg: byvoorbeeld om terselfdertyd die verteltrant van die oorspronklike verteller te probeer behou, maar ook die taalgebruik te verbeter (Von Wielligh, 1917:6); om die "gedagtegang" van sowel die inheemse verteller as die "blanke bevolking" in gedagte te hou (Von Wielligh, 1922a:3). Uit die weergawe van die vertellings blyk dus 'n bepaalde onsekerheid of dubbelslagtigheid, wat veral na vore kom in die beskouings oor die taal en godsdiens van die Boesmans.

Die besondere waarde wat die Boesmanvertellings vir Von Wielligh ingehou het, het beslis te make met sy belang by die vestiging van Afrikaans as skryftaal. Op grond van die manier waarop die Khoekhoen en Boesmans Afrikaans gepraat het, moes Von Wielligh besef het dat hy hier met ' $n$ kernaspek van die ontstaan van die taal te doen het. Afgesien van linguistiese waardering, toon Von Wielligh ook groot bewondering vir veral die Boesmans se vertelvermoëns, met ander woorde die narratiewe dimensies van hul verhale. Ter illustrasie van dié vermoëns word waterslangverhale as voorbeelde gebruik (Von Wielligh, 1920a:ii). Hy toon dus op 'n manier begrip vir die mitiese dimensies van die Boesmans se religie, maar terselfdertyd is hy baie krities ten opsigte van hul godsdiensbelewing. Die rede hiervoor is dat Von Wielligh, soos blyk uit sy voorwoorde en ook gedeeltes uit Jakob Platjie, die "ware" religie, as teken van beskaafdheid, slegs in die vorm van geïnstitusionaliseerde godsdiens beskou, met "priesters, eredienste en kerke" (Von Wielligh, 1921a:43) as sigbare tekens. Hy toon dus in 'n groot mate begrip vir die mitiese dimensies van die Boesman se kuns en religie, maar sy vaste interpretasie van religie as georganiseerde "godsdiens" weerhou hom daarvan om hulle op bewuste wyse as geïntegreerde dimensies te begryp en waardeer.

Die implikasies hiervan vir sy eie, kreatiewe verwerking van die Boesman- en Khoekhoen-oorlewerings blyk duidelik uit die roman

aansluiting by pogings om die woord van sy negatiewe konnotasies te suiwer (vgl. Van Vuuren, 1995:25). 
Jakob Platjie. Die gelyknamige hoofkarakter swerf vanaf twaalfjarige ouderdom saam met die smous Koos Fonk. As gevolg van die baie reise wat hulle onderneem, ervaar en hoor Jakob vele dinge. Die roman bestaan uit 'n groot verskeidenheid drink-, jag- en oorlogstories. Jakob Platjie ontwikkel nie eintlik as karakter nie, maar dien slegs as 'n soort katalisator om 'n verskeidenheid insidente en verhale te inisieer of aan te hoor. Een so 'n insident is 'n ontmoeting met 'n waterslang. In Hoofstuk 9, met die opskrif, "Is dit Bygeloof of is dit waar?", word vertel van Karel Bleskop, 'n ou Koranna-man wat 'n "ekspert in bygelofies" (p. 90)4 was. Wanneer Jakob vir Karel uitvra na die land waar hy vandaan kom, vertel Karel van 'n man "oorkant die Grootrivier", ene Filies Lou Kreebos, wat 'n baie besondere mens was omdat hy 'n besondere verhouding sou hê met die waterslang, met die steen wat in die sonlig blink (p. 93). Daar is geen verdere verwysings na die waterslang in die roman nie, sodat ' $n$ mens tot die gevolgtrekking kan kom dat dit hier, anders as in die vertellings, bloot as bygeloof gesien word.

Die gebrek aan ontginning van die spanning tussen narratiewe en numineuse dimensies blyk ook duidelik uit die slot van die roman. Ná jare van vele omswerwinge beland Jakob op die sendingstasie Genadendal: "Jare lank het Platjie op Genadendal gebly, waar hy die Kristelike leer aangeneem en bely het" (p. 218). Dit is eers as Platjie tot die Christendom bekeer word dat hy, in die oë van sy "skepper", Von Wielligh, enigsins 'n mate van waardigheid bereik. Wat meer is, is dat dié bekering, by wyse van spreke, binne die gedeelte van 'n sin plaasvind. Verskeie kritici, onder andere Smuts (1975) en Hugo (1985), wys daarop dat die ingrypende karakterverandering geensins vanuit die gebeure gemotiveer word nie. Dit is wel duidelik in ooreenstemming met Von Wielligh se siening van geïnstitusionaliseerde godsdiens as die enigste vorm van "beskaafde" religieuse belewing.

Daar is gevolglik geen geïntegreerde erkenning van die Griekwa of Boesman as "Ander" in die sin van 'n volwaardige persoon met 'n eie, selfstandige religieuse aanvoeling nie. Dit is hierdie keuse vir oorvereenvoudiging wat daartoe lei dat Von Wielligh die moontlikhede van mitisiteit, wat hy ten opsigte van die Boesman- en Khoivertellings so sterk aangevoel het, in Jakob Platjie prysgee. Deur die waterslang, wat 'n prominente rol in spesifiek die Boesman-

4 Bladsynommers tussen hakies verwys na Von Wieligh, G.R. 1922b. Jakob Platjie. Pretoria : De Bussy. 
vertellings speel, sonder meer in die roman tot "bygeloof" te degradeer, ontken hy die numineuse moontlikhede van dié argetipiese simbool. Daar is geen sprake meer in Jakob Platjie van vraagstelling of problematisering wanneer dit kom by die uitbeelding van mitologiese elemente soos die waterslang nie. Die roman eindig met 'n oorvereenvoudigde, moralistiese "oplossing" van bekering tot die Christendom. As gevolg van Von Wielligh se beperkte siening van religie as georganiseerde godsdiens, word sy potensiaal as werklik kreatiewe skrywer verskraal en word sy werk hoofsaaklik geag in terme van die kultuurhistoriese waarde daarvan (vgl. Schoonees, 1939:91). In plaas daarvan om 'n eie - dalk selfs profetiese visie - te gee, op die basis van sy interkulturele kennis en ervaring, skryf Von Wielligh in Jakob Platjie hoofsaaklik in diens van eng Christelik-nasionale strewes.

Nog 'n roman waarin oordrewe moralisering die potensiële werking van mitisiteit teëwerk, is Meraai van Rolbos (1989) deur Charlotte de Beer. Dit is des te meer jammer, omdat die inisiasierituele van die Griekwabevolking, as een van die belangrikste oorsprongsituasies van die waterslangsimboliek, 'n sentrale rol in die verhaal speel.

Die hoofkarakter is Meraai, 'n jong Griekwameisie, wat saam met die res van haar familie deel uitmaak van die klein Griekwagemeenskap op die plaas Rolbos in die destydse Oranje-Vrystaat. Hoewel daar in die "vooraf-tekste" deur die skrywer ('n opdrag, erkenning en verduidelikings) geen eksplisiete aanduiding is dat dit gaan om die uitbeelding van 'n leefwyse wat besig is om verlore te gaan nie, is dié intensie duidelik uit die teks afleibaar. Sommige van die belangrikste tradisionele gebruike van die Griekwas word uitgebeeld, waaronder die inisiëringsritueel, die sogenaamde !njabasas (p. 135-144). 5

Die oorgang van die een lewensfase na 'n ander geskied by Meraai nie sonder probleme nie. Daar is veral drie konflikterreine in haar lewe: haar puberteit, haar verhouding tot haar ouers en ander grootmense, en haar godsdiensbelewing. Al haar vrese hou op een of ander manier verband met die waterslang, maar dit is veral die veranderinge by haar eie liggaam wat sy assosieer met haar vrees vir die waterslang. Die wending in die roman kom wanneer Meraai se "maandsiekte" (p. 134) begin. Deur middel van die spesifieke

5 Bladsynommers tussen hakies verwys na De Beer, Charlotte. 1989. Meraai van Rolbos. Pretoria : Van der Walt. 
inisiëringsrituele, onder meer die strooi van boegoe oor die rivier waar Waterslang woon, word haar vrees vir die slang besweer: "Die mense op die wal weet dat hy nou stil-stil na sy huis onder die water sal verdwyn" (p. 142). Ná hierdie frase is daar geen verdere verwysing na die waterslang in die res van die verhaal nie. Wat volg, is ' $n$ reeks bekerings wat die oplossing vir die res van Meraai se probleme bring. Al die grootmense se probleme word opgelos, hoofsaaklik omdat hulle begin glo in "Daai Here van ... Meraai" (p. 208).

Die gelukkige einde van die roman bied egter nie 'n oplossing vir vrae ten opsigte van die uitbeelding van die numineuse dimensies wat deur die teks self opgeroep word nie. Enersyds word daar uitvoerig aandag gegee aan die Griekwa-tradisies, waarby die rol van die waterslang ingesluit is. Andersyds word dié tradisies as van verbygaande aard uitgebeeld. Dit is opvallend dat Meraai self nooit die saambestaan van haar Christelike geloof en haar vrees vir die waterslang as 'n religieuse probleem ervaar nie. Die waterslang word eerder in verband gebring met haar seksuele gewaarwordinge. Dit wil voorkom asof die skrywer die rol van die mite-diskoers in die teks onderskat; asof daar nie geskryf word vanuit die besef dat die skryfhandeling as sodanig ook mitiese implikasies mag inhou nie. Deur oor die waterslang in 'n nuwe konteks te skryf (in hierdie geval die verhaal van Meraai), ontstaan die moontlikheid om daarvan opnuut 'n "lewende" simbool te maak, sodat dit nie sonder meer afgeskryf kan word as bloot 'n antropologiese kuriositeit behorende tot die verre verlede nie. Die belangrikste rede vir hierdie verskraling is naamlik dat die inherent-religieuse en numineuse dimensies van die waterslang, in teenstelling tot die Christelike tradisie, nie werklik ernstig geneem is nie.

\section{Gevolgtrekkings}

Uit die voorafgaande analises het geblyk dat selfs al sou die skrywer die doelbewuste intensie hê om die numineuse te deurgrond, dit nie noodwendig beteken dat dit binne die narratiewe dinamiek van die struktuurelemente van die teks so gebeur nie. Deurdat onbewuste elemente bykom waarmee die skrywer nie altyd rekening hou nie, ontstaan die dinamiese spanning tussen skrywers- en teksintensie. 'n Interessante aspek rondom interkulturele en intertekstuele verhoudinge wat feitlik deurgaans in Afrikaanse waterslangverhale na vore tree, is dat die tradisionele Afrikagodsdiens op een of ander wyse in gesprek tree met die Christelike geloof. Die skrywer gee bepaalde intensies of visies ten opsigte van hierdie soort ver- 
houdings op minder of meer eksplisiete wyses weer, maar dit bly die taak van die leser om die intensies te toets aan die intrinsieke werkinge van die teks. In die geval van die mitiese teks het dergelike interpretasieprosesse in die eerste plek te make met die wisselwerking tussen numineuse en narratiewe dimensies. Die relevansie van die voortgesette mitiese werking al dan nie het te make met hierdie spanning of wisselwerking binne bepaalde historiese kontekste.

Op grond van die bespreking van sowel George Weideman se Die donker melk van daeraad as André P. Brink se Die eerste lewe van Adamastor het geblyk dat daar afbreuk gedoen word aan die potensiële mitisiteit as gevolg van oormatige assosiëring. Dit gebeur wanneer die skrywer die historiese tradisie rondom die waterslangsimboliek - in albei gevalle dié van die Khoesaan-mitologie in 'n sekere sin buite rekening laat en uit eie verbeelding 'n netwerk van nuwe assosiasies en parallelle rondom die waterslangsimbool opbou. By Weideman is dit in mindere mate die geval as by Brink, omdat sy bundel ook talle voorbeelde bevat waar die mitiese assosiasies rondom die waterslang op oortuigende wyse binne die verlengstuk van die tradisie relevant gemaak word. Weideman slaag daarin om deur middel van veral die steensimboliek sosiaal-politieke kommentaar te lewer wat nie sonder meer oorvereenvoudigde ideologiese keuses veronderstel nie.

In Brink se novelle word 'n verdere oorsaak van die verskraling van mitisiteit geïllustreer, naamlik die oorbeklemtoning van die historiese konteks ten koste van die numineuse dimensies van die verhaal. Deurdat Brink, via sy verteller, 'n definitiewe ideologiese keuse doen vir die Afrika-tradisie téénoor die Westerse invloede, word 'n te maklike oplossing voorgehou wat die probleemstellende aard van die numineuse ondermyn. Die einde van die Adamastor-verhaal, met die geboorte van 'n kind as simbool van versoening, dra voorts daartoe by dat die spanning tussen narratiewe en numineuse aspekte nie voldoende volgehou word ten einde die mitisiteit van die verhaal op werklik geslaagde wyse na vore te laat tree nie.

In die romans van onderskeidelik Von Wielligh en Charlotte de Beer word die relevansie van die mitiese dimensie nadelig beïnvloed deur 'n verskynsel wat nóú met ideologisering verband hou, naamlik oormatige moralisering. Dit is veral in tekste waar die spanning tussen Afrika- en Westers-geöriënteerde religieë opgeroep word, waar 'n definitiewe keuse mitisiteit nogeens teenwerk. Die ongemotiveerde bekerings tot die Christendom in albei verhale het tot gevolg 'n inperking van die interkulturele diskussie wat in die teks na 
vore sou kon tree, soos aan die orde gestel deur die waterslangsimboliek. In sulke gevalle word die verwysing na die waterslang nie veel meer as net die bybring van 'n mitologiese simbool nie, sonder dat die mitiese relevansie daarvan na behore ontgin word.

Daar is veel uitvoeriger aandag aan die Weideman-bundel gegee, omdat dit as een van die mees geslaagde tekste in Afrikaans beskou kan word ter illustrasie van die relevante voortsetting van ' $n$ oeroue mitologiese simbool soos die waterslang. Afgesien van 'n balans tussen narratiewe en numineuse aspekte, ontgin Weideman ook op indrukwekkende wyse die paradoksale samehang tussen enersyds noukeurige aandag aan 'n bepaalde historiese konteks en andersyds universaliserende betekenisprosesse. Hy fokus in eerste instansie op die streek van die Noord-Kaap met sy ryk mondelinge tradisie, maar betrek terselfdertyd - deur middel van kreatiewe assosiëring - verwante verskynsels aan die waterslang, uit die streek maar ook uit ander wêreldmitologieë. Dit is binne hierdie soort wisselwerking dat waterslangverhale 'n belangrike bydrae tot groter interkulturele en interreligieuse begrip kan lewer. Daar word op implisiete wyse gemaan om, vanuit die eie perspektief en geskiedenis, die Ander se religieuse belewing nie sonder meer as "bygeloof" af te maak nie. Vanuit so 'n numineuse ingesteldheid is daar nie veel sprake van die verskraling van mitisiteit as gevolg van oormatige moralisering of ideologisering nie.

'n Laaste en belangrike vraag wat spesifiek Weideman en Brink se verhale na vore gebring het, is naamlik of daar ander vorme van mitisiteit bestaan naas verhale met ' $n$ definitiewe religieuse inslag. Die postmodernistiese dimensies in byvoorbeeld Weideman se werk behoort moontlikhede van vergelyking te open met verhale wat binne 'n veel meer sekulêre tradisie ontstaan. Die basis vir mitisiteit - die numineuse vraagstelling - sou byvoorbeeld verband kon hou met 'n ekologiese bewussyn, sonder dat spesifieke religieuse tradisies betrek word.

Die intrinsieke verband tussen orale ekspressie en ekologiese verantwoordelikheid is 'n verdere aspek wat moontlikhede inhou vir ander vorme van mitisiteit as dié wat primêr verband hou met die literêre ekspressie in skriftelike vorm. Mitisiteit binne die Afrikakonteks betrek dikwels vorme van orale ekspressie binne die skriftelike, literêre vormgewing. Waterslangverhale in Afrikaans illustreer by uitstek hierdie tendens. Die uitgangspunt van mitisiteit in talige, hoofsaaklik skriftelike vorm, soos dit na vore getree het in die voorafgaande teksanalises, kan dus gekwalifiseer word ten einde 
nie-talige vorme van werklikheidsbelewing in te sluit. Ander vorme van kommunikasie, waaronder seksualiteit, dans en musiek, sou as verlengstukke van mitisiteit in verhalende vorm gesien kon word.

Die noue samehang tussen religie en seks is 'n tema wat algemeen in André P. Brink se skryfwerk voorkom. Hierdie beskouing is ook relevant vir Die eerste lewe van Adamastor. Dit het geblyk dat die numineuse vraagstelling in die novelle eerder tereg kom binne die kader van die verhouding tussen man en vrou - met name die seksuele problematiek - as die mens se verhouding tot God. Die verband tussen liggaamlikheid en ander vorme van mitisiteit is 'n terrein wat verder ondersoek kan word. Dié vraagstelling hou voorts verband met die meer intuïtiewe kommunikasie van die mondelinge vorme: religiositeit wat eerder intuïtief as rasioneel begryp word.

Hierdie soort verfyning van die mitisiteitsbegrip word in die eerste plek bewerkstellig deur die noukeurige ontleding van tekste wat die numineuse vraagstelling rondom 'n bepaalde mitologiese simbool werklik ernstig neem. Om Gould (1981:178) nogeens aan te haal: "intentionality is all: the intention especially to confront the unanswerable". Ander waterslangverhale in Afrikaans waar die problematiserende aard van mitisiteit die relevansie daarvan waarborg, is onder meer: Witwater se mense deur M.I. Murray (1974), Rooigrond deur Thomas Deacon (1995), Uit die omtes van die hart (1995) deur Petra Müller en lets goeds uit Verneukpan (1998) deur Elias P. Nel.6 As daar ruimte sou gewees het vir die ontleding van hierdie tekste, sou die volgende aspekte aandag kon geniet: die hiërargiese inbedding van waterslangverhale; die noodsaak al dan nie van bygeloof (in die sin van by-geloof); die onlosmaaklike samehang tussen mitisiteit en ironie, paradoks, humor. Die interpretasieproses kan dus voortgesit word, met steeds die potensiële relevansie van mitisiteit as gevolg.

\section{Geraadpleegde bronne}

Aucamp, H. 1994. Radioresensie van Die donker melk van daeraad deur George Weideman, p. 1-6, Aug. 18.

6 In Hoofstuk 5 van Lombard (1999) word hierdie tekste uitvoerig bespreek, terwyl die verhale wat in die voorafgaande onderafdelings ter sprake was, in veel meer detail ontleed word. 'n Afsonderlike hoofstuk (Hoofstuk 6) word gewy aan vergelykingsmoontlikhede van die Afrikaanse verhale met onder meer Engelsen Nederlandstalige tekste. 
Brink, André P. 1988. Die eerste lewe van Adamastor. Kaapstad : Saayman \& Weber.

Deacon, T. 1995. Rooigrond. Kaapstad : Tafelberg.

De Beer, C. 1989. Meraai van Rolbos. Pretoria : Van der Walt.

Gould, E. 1981. Mythical intentions in modern literature. Princeton : Princeton University Press.

Hugo, D.J. 1985. Griekwa-Afrikaans in die Afrikaanse letterkunde. In: Van Rensburg, M.C.J. (red.) Die Afrikaans van die Griekwas van die tagtigerjare. Ongepubliseerde verslag. p. 585-608.

Jansen, E. 1994. Gekomponeerde bundel. De Kat: 54, Des.

Jung, C.G., ed. 1964. Man and his symbols. New York : Laurel.

Lombard, J. 1988. Die komplisering van die verhaaleinde as postmodernistiese verskynsel. Tydskrif vir Literatuurwetenskap, 4(4):459-471, Des.

Lombard, J. 1999. Waterslangverhale in en rondom Afrikaans: 'n ondersoek na mitisiteit as basis vir vergelykende literatuurstudie. Potchefstroom : PU vir CHO. (Proefskrif - Ph.D.)

Le Roux, J. 1994. Die dagstêrwals. Kaapstad : Human \& Rousseau.

Müller, P. 1995. In die omtes van die hart. Kaapstad : Tafelberg.

Murray, M.I. 1974. Witwater se mense. Kaapstad : Tafelberg.

Nel, E.P. 1998. lets goeds uit Verneukpan? Kaapstad : Tafelberg.

Nel, E.P. 2001. Mafoiing. Kaapstad : Tafelberg.

Postma, M. 1986. As die maan oor die lug loop: Sotho-verhale. 'n Keuse saamgestel deur Hennie Aucamp. Kaapstad : Tafelberg.

Pritchard, J.B. (red.) 1958. The ancient Near East. Princeton : Princeton University Press.

Schoonees, P.C. 1939. Die prosa van die Tweede Afrikaanse Beweging. Pretoria : De Bussy.

Smuts, J.P. 1975. Karakterisering in die Afrikaanse roman. Pretoria : HAUM.

Van Rensburg, M.C.J. (red.) 1985. Die Afrikaans van die Griekwas van die tagtigerjare. Ongepubliseerde verslag.

Van Rooyen, P. 2001. Gif. Pretoria : Protea Boekhuis.

Van Vuuren, H. 1995. Die mondelinge tradisie van die /Xam en 'n herlees van Von Wielligh se Boesman-Stories. Tydskrif vir Letterkunde, 31(1):25-35, Feb.

Von Wielligh, G.R. 1917. Diere Stories, soos deur Hotnots vertel. Deel 1. Pretoria : Van Schaik.

Von Wielligh, G.R. 1920a. Boesman-Stories. Deel 2: Dierstories en ander verhale. Kaapstad : Nationale Pers.

Von Wielligh, G.R. 1921a. Boesman-Stories. Deel 3: Die Boesman self, sy sedes, gewoontes en bekwaamhede. Kaapstad : Nationale Pers.

Von Wielligh, G.R. 1922a. Diere Stories, soos deur Hotnots vertel. Deel 4. Pretoria : Van Schaik.

Von Wielligh, G.R. 1922b. Jakob Platjie. Egte karaktersketse uit die volkslewe van Hotnots, Korannas en Boesmans. Pretoria : De Bussy.

Weideman, G. 1993. Van halfmense en volmense. Tydskrif vir Letterkunde, $31(4): 6-14$, Nov.

Weideman, G. 1994. Die donker melk van daeraad. Kaapstad : Tafelberg.

Weideman, G. 1995. Bespreking van Die donker melk van daeraad, Welgelegen-leeskring, p. 1-23, Junie 21.

Winton Thomas, D. (ed.) 1958. Documents from Old Testament times. New York: Harper \& Row. 


\section{Kernbegrippe:}

mitisiteit

waterslangverhale in Afrikaans

Key concepts:

mythicity

water snake stories in Afrikaans 
